\title{
FENOMENA SALAFI DI KALIMANTAN SELATAN
}

\author{
Takdir Ali Syahbana \\ Alumni Fakultas Ushuluddin dan Humaniora \\ IAIN Antasari Banjarmasin
}

Diterima tanggal 13 November 2014 / Disetujui tanggal 18 Desember 2014

\begin{abstract}
Salafi is one of Islamic movement which have spread around the world. This movement initiates to purify Islamic doctrine from what it called bid'ah. It has been currently in South Kalimantan for several years. In fact, the movement has several places that be the center of its teaching. Data showed that Ustadz. Aiman and his brother introduce it at the first in 2001. Since that time, Salafi has developed and has had many followers. In several big cities of South Kalimantan district, such as Banjarmasin, Martapura, and Barabai, Salafi built some mosques and used it as its learning and teaching center. This writing discussed about the development of Salafi movement in South Kalimantan. It will be reviewed about Salafi's methods in introducing and teaching its doctrine to the people of South Kalimantan.
\end{abstract}

Kata kunci: Salafi, Perkembangan, Kalimantan Selatan

\section{Pendahuluan}

Kalimantan Selatan dengan ibukota provinsi Banjarmasin adalah salah satu provinsi di Indonesia yang mayoritas penduduknya beragama Islam. Masyarakat Kalimantan Selatan yang biasa disebut dengan Orang Banjar adalah masyarakat yang dikenal dengan kedalaman pandangan dan pengetahuan keagamaannya. Hal ini dapat dilihat dari sejarah Kalimantan Selatan yang banyak melahirkan tokohtokoh agamawan yang sangat dihormati, ditaati dan menjadi rujukan bagi masyarakat muslim nusantara seperti Syekh Arsyad al Banjari, K.H. M. Zaini Ghani, K.H. Nuruddin Marbu’ dan lain-lain.

Besarnya perhatian masyarakat Banjar dalam kehidupan beragama membuat suburnya pahampaham keagamaan yang masuk ke Kalimantan Selatan. Jamaah Tabligh, Hizbut Tahrir, LDII, Ikhwanul Muslimin tumbuh dan berkembang di Kalimantan Selatan. Salah satu paham keagamaan yang relatif baru dan tumbuh subur sekarang adalah kelompok Salafi. Salafi (mufrad) dan salafiyyun (jama') mempunyai arti yaitu orang-orang yang bermanhaj kepada salaf dengan mengamalkan apa-apa yang ada pada al-Qur'an dan Sunnah secara murni sebagaimana yang telah para Sahabat lakukan, maka orang-orang inilah yang dinamakan dengan Ablu al-Sunnab wa al-Jama'ah. Di Indonesia khususnya, Salafi terbagi kepada dua kelompok, yaitu Salafi Yamani dan Salafi Haraki. Walaupun pembagian ini masih kontroversi, untuk mempermudah pembahasan penggunaan istilah Salafi Yamani dan Salafi Haraki ini digunakan dan fokus pembahasan ini adalah Salafi Haraki yang ada di Kalimantan Selatan.

\section{Pengertian Salafi}

Pengertian kata salaf dapat dibedakan ke dalam tiga maksud. Pertama, kata salaf secara etimologi (bahasa), berasal dari kalimat salafa, yaslufu, salafan yang artinya adalah telah lalu, sebagaimana terdapat dalam sebuah peribahasa al-Qaum al-Sullâf yang artinya kaum yang terdahulu, dan dalam frase lain salafu al-rajuli yang artinya adalah bapak-bapak mereka yang telah terdahulu. Di lain kalimat juga terdapat kata al-Sulfah yang artinya adalah; makanan ringan yang dimakan sebelum sarapan, al-Tasliff 
artinya pendahuluan, kemudian al-Sâlif yang artinya orang-orang terdahulu. Dari definisi ini jelaslah bahwa secara bahasa kata salaf mempunyai makna orang-orang yang telah terdahulu baik secara ilmu, iman, keutamaan dan juga kebaikan, hal ini sesuai dengan apa yang telah dikatakan oleh Abu Manzhur Ra. bahwa, kata salaf adalah arti dari orang-orang yang telah mendahului baik dari bapak ataupun keluarga yang lebih tua, baik secara umum maupun secara ilmu pengetahuan. Rasulullah bersabda kepada putrinya (Fathimah): "Sesunggubnya sebaik-baik Salaf (pendabulu) bagimu adalah aku" (HR.Muslim). Dan sabda Rasulullah Saw. yang ditujukan kepada Zainab (putri Rasulullah) ketika dia meninggal dunia: "Susullah Salaf al-Shâlih kita (pendabulu kita yang salib) yaitu Ustman ibn Mą̧h'un." (HR. Ahmad).

Kedua, kata salaf diartikan secara terminologi (istilah) adalah sifat yang ditujukan kepada para Sahabat Rasulullah Saw. Ketika ada muncul perkataan salaf maka yang dimaksud adalah para Sahabat, namun tidak baku hanya pada konteks Sahabat saja, kata salaf digunakan juga untuk orang-orang yang mengikuti ajaran Rasulullah Saw. dan juga para Sahabat, hal ini juga berdampak pada penambahan kata pada kalimat salaf, ketika orang mengikuti para Sahabat maka kata salaf berubah menjadi salafiyyin (orang-orang yang mengikuti Salaf al-Shâlih). Namun penggunaan kata salaf secara terminologi tidak merujuk pada firman Allah Swt.

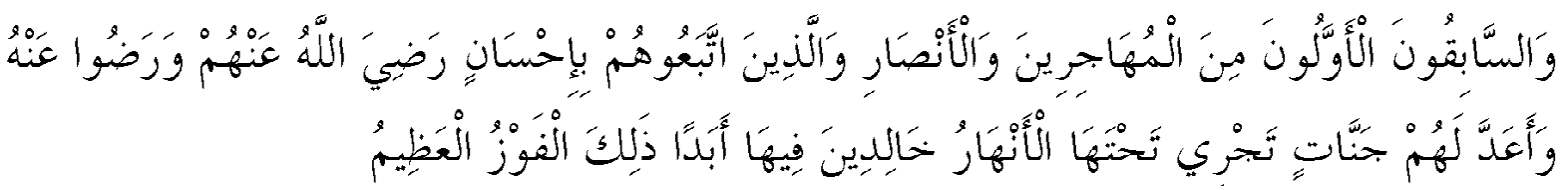

"Orang-orang yang terdahulu lagi yang pertama-tama (masuk Islam) dari golongan mubajirin dan anshar dan orang-orang yang mengikuti mereka dengan baik, Allah ridha kepada mereka dan merekapun ridha kepada Allah dan Allah menyediakan bagi mereka surga-surga yang mengalir sungai-sungai di dalamnya selamalamanya. Mereka kekal di dalamnya. Itulah kemenangan yang besar.” (QS. al-Taubah: 100).

Pada dasarnya, ayat di atas menjelaskan bahwa generasi pertama umat Islam adalah para sahabat yaitu dari kalangan Muhajirin dan Anshar, mereka semua adalah orang-orang yang telah mendapatkan keridhaan yang pasti dari Allah Swt. dan dijamin surga bagi mereka, dan orang-orang yang mengikuti ajaran mereka secara murni baik aqidah maupun manhaj. Hal ini senada dengan firman Allah Swt.:

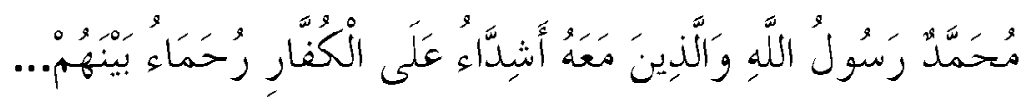

"Muhammad itu adalah utusan Allah dan orang-orang yang bersama dengan Dia adalah keras terhadap orang-orang kafir, tetapi berkasib sayang sesama mereka ...” (QS. al-Fath: 29).

Ketiga, pengertian salaf merujuk pada zaman, kata salaf ditunjukan kepada sebaik-baik kurun atau masa dalam catatan sejara Islam, masa tersebut adalah tiga masa yang telah diakui dalam sabda Rasulullah Saw.: "Sebaik-baik manusia adalah pada masaku (masa para sahabat) kemudian yang sesudahnya (tâbi'în) kemudian masa sesudahnya lagi (tâbi' al-tâbi'în)." (HR. Bukhari Muslim). Dalam hadis lain juga dikatakan bahwa: "Sebak-baik manusia adalah generasiku kemudian generasi seseudahnya, kemudian generasi sesudahny a lagi, kemudian datang kaum yang kesaksian salah seorang di antara mereka mendahului sumpahnya dan sumpahnya mendabului kesaksiannya.” (HR. Ahmad, Bukhari dan Muslim). Tiga masa ini adalah masa yang telah diakui oleh sebaik-baik manusia (Nabi Muhammad). Namun jika kata salaf hanya dipandang dari segi zaman, baik pada zaman Rasul hingga zaman para Sahabat hal ini tentu tidak menunjukan sesuatau yang semuanya baik, sejarah mencatat bahwa pada zaman Rasulullah dan juga 
zaman para Sahabat banyak terjadi penyimpangan-penyimpangan yang tergolong bid'ah yang mengkristal menjadi sebuah sekte, oleh karena itu penggunaan kata masa pada definisi salaf tidak cukup, banyak sekali muslimin yang mengaku dirinya berpahamkan salaf namun tidak seperti salaf sebenarnya yang menjalankan al-Qur'an dan Sunnah secara murni namun masih banyak yang melakukan penyimpangan-penyimpangan, untuk itu agar kata salaf tetap terarah sebagaiman haknya maka perlu ditambahkan suku kata baku pada bagian akhirnya yaitu al-Salaf al-Shâlih (pendahulu yang salih).

Untuk itulah ketika kata salaf digunakan bukan berarti salaf hanya menunjukan masa, tetapi di dalam kata salaf mengandung unsur-unsur kesalehan yang sesuai dengan al-Qur'an dan Sunnah yang tepatnya pada masa para Sahabat dan terus kepada pengikut Sahabat. Yazid ibn Abdul Qadir mengatakan bahwa salaf adalah suatu manhaj yang benar yang mencoba untuk megembalikan sebuah alur pikir sebagaimana masa Rasulullah dan para Sahabat yang tidak ada perselisihan paham dan juga perpecahan dalam kubu Muslim sendiri.

Dalam penjelasan makna Salafi di sini terdapat tiga fase yang mencoba utuk menerapkan kembali makna salaf tersebut menjadi sebuah paham sebagai petunjuk jalan agama di saat meredupnya pemikiran di dunia Islam. Fase ini disebut dengan fase reformasi yang dikaitkan kepada Imam A hmad

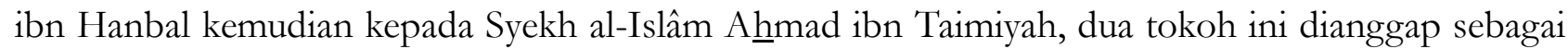
pendiri gerakan Salafiyah. Di sisi lain gerakan Salafi juga dikaitkan dengan gerakan Wahabi yang didirikan oleh Munammad ibn Abdul Wahhạb al-Musyrifi al-Najadi.

Sejarah paham Salafi pertama kali masuk ke-Indonesia sekitar tahun 1798 hingga tahun 1803 yang dimulai dari tiga orang yang berasal dari Minangkabau pergi ke Tanah Suci Makkah dan Madinah untuk melaksanakan ibadah haji, yang pada tahun tersebut Kota Makkah sedang mengalami revolusi pemikiran dan juga perpolitikan yang dipelopori oleh Wahabi.

Pada tahun 1804 tiga orang tersebut datang kembali ke Minangkabau. Haji Miskin yang berasal dari Pandai Sikat, Haji Sumanik yang berasal dari Luhak Tanah Dasar, Haji Piabang yang berasal dari Luhak 50-Koto. Tiga orang jamaah haji yang berasal dari Minangkabau tersebut mempelajari apa yang didakwahkan oleh Wahabi di Makkah, oleh sebab itu ketika mereka kembali ke Minangkabau mereka menyadari bahwa banyak sekali kesesatan-kesesatan yang terjadi di daerah asal mereka seperti judi, pemerkosaan, pembunuhan, perampokan, mabuk-mabukan, mengadu ayam, yang semuanya bertentangan dengan ajaran Islam. Fenomena ini tentu membuat tiga orang haji ini bertekad ingin merubahnya agar superioritas ajaran Islam kembali murni dengan mengaplikasikan pemahaman Wahabi di Minangkabau.

\section{Sejarah Dakwah Salafi di Kalimantan Selatan}

Berawal di daerah Amuntai, tepatnya di rumah seorang Ustadz Muda yang bernama Ustadz Aiman dan saudara kandungnya Mardatillah. Pada tahun 2001, Aiman yang masih menempuh pendidikan kelas 2 SMA sederajat di salah satu pendidikan Salafi al-Irsyad, pulang ke kampung karena liburan sekolah, pada masa liburan itulah Aiman mulai ceramah di masjid-masjid Muhammadiyah. Pada tahun ini organisasi Muhammadiyah di daerah Amuntai dan Alabio sudah berkembang cukup besar.

Dakwah Salafi pertama kali bukan dimulai dari masjid-masjid Salafiyah, namun berangkat dari masjid-masjid Muhammadiyah di Amuntai. Sejak tahun 2001 hingga tahun 2005 hanya Aiman dengan Mardatillah yang berdakwah dari masjid ke masjid, rumah ke rumah untuk mendakwahkan Manhaj Salafi kepada penduduk Amuntai. Setelah tahun 2005, ketika Aiman aktif sebagai Jamaah Tablig, dia berangkat ke Tasik dan bertemu dengan seorang ustadz yang bernama Febri. Dalam pertemuan itu 
Aiman membujuk agar Febri bisa berdakwah di Kalimantan Selatan dan ajakan itu dikabulkan oleh Febri. Setelah tiba di Amuntai, Ustadz Febri langsung ditugaskan oleh Aiman untuk mengisi ceramah di masjid-masjid Muhammadiyah.

Pada tahun 2005, pendakwah Salafi di Kalimantan Selatan bertambah menjadi tiga orang, Aiman, Mardatillah dan Febri. Dengan dalamnya keilmuan yang dimiliki oleh tiga orang ustadz ini dalam bidang keislaman maka mereka mampu melebarkan dakwah mereka hingga ke masjid-masjid Muhammadiyah di Tanjung, Kandangan dan juga Barabai.

Pada tahun 2006, ada seorang ustadz alumni Mesir yang juga sering ceramah di masjid-masjid Muhammadiyah dan juga masjid NU. Pada waktu itu, Aiman mencoba untuk mendekati dia, dan berbincang-bincang masalah Sunnah dan menjelaskan tentang Manhaj Salafi dan dia diberi oleh Aiman beberapa buku yang membahas tentang Manhaj Salafi dan diajak oleh Aiman menghadiri dauroh di Malang yang dihadiri oleh syekh-syekh dari Arab Saudi. Pada waktu inilah, ustadz baru ini sadar dan menyatakan bersungguh-sungguh akan berdakwah menegakkan Manhaj Salafi. Dia adalah Ustadz Hasbi Ridhani. Masuknya Ustadz Hasbi ke dalam dakwah Salafi di Kalimantan Selatan menambah pendakwah Salafi pada tahun 2006 menjadi 4 orang yaitu Ustadz Aiman, Ustadz Mardatillah, Ustadz Febri dan Ustadz Hasbi.

Pada tahun 2006 juga, Aiman kembali bertemu dengan seorang ustadz alumni Madinah, yaitu Ustadz Ahmad Zainuddin. Aiman mengajak Ustadz Zainuddin untuk mengisi ceramah-ceramah agama di masjid Muhammadiyah Amuntai. Ada cerita yang menarik antara Ustadz Aiman dengan Ustadz Ahmad Zainuddin. Ketika Aiman masih menempuh pendidikan kelas 2 SMP di Pesantren Salafi alIrsyad, dia bertemu dengan Ustadz Ahmad Zainudiin di Musholla Kapal Egon. Ketika pertemuan ini, Ustadz Ahmad Zainuddin baru selesai tes ujian untuk mendaftarkan diri ke Madinah. Pertemuan di musholla tersebut dihiasi dengan perdebatan-perdebatan masalah Sunnah, hal ini karena perbedaan pemahaman antara Ustadz Zainuddin yang mendalami masalah tarekat, murid kesayangan salah satu ulama tarekat di Banjarmasin, yang menempuh pendidikan di Kudus dengan Aiman yang menempuh pendidikan Al-Irsyad (Ma’had Salafi).

Saat Zainuddin menempuh pendidikan di Madinah, dia mulai paham dan kenal dengan yang namanya Salafi dan mengakui kebenaran Salafi. Oleh sebab itulah, ketika kembali ke Kalimantan Selatan dia langsung menemui Aiman. Aiman kemudian menawarkan kepada Zainuddin untuk mengisi ceramah agama di Amuntai. Sejak saat itu, pendakwah Salafi di Kalimantan Selatan bertambah menjadi lima orang.

Pada tahun 2005, sebelum Aiman pergi ke Madinah untuk menempuh pendidikan, dia sempat ceramah di salah satu langgar di dekat Masjid At-Taqwa (masjid Muhmmadiyah Martapura) langgar tersebut bernama An-Nur, dia mengsisi ceramah di langgar tersebut dan ketika selesai ceramah, ada satu jamaah yang mendekati Aiman dan mengajukan satu pertanyaan, “jika kami mendirikan masjid apakah Ustadz bersedia untuk mengurus masjid tersebut hingga menjadi tempat berkumpulnya Salafi di Martapura". Pertanyaan tersebut langsung dijawab oleh Aiman, "iya sanggup”. Setelah itu Aiman pergi ke Madinah dan kembali ke Kalimantan Selatan tahun 2009 dan masjid Syarifah Sholehah hampir selesai, sehingga masjid tersebut menjadi pusat dakwah Salafi di Martapura dan Banjarbaru khususnya

Tahun 2006, setelah Aiman pergi ke Madinah, dakwah dijalankan oleh Mardatillah, Hasbi dan Febri. Pada tahun ini, mereka diundang untuk mengisi ceramah di salah satu masjid Muhammadiyah Banjarmasin yaitu Masjid al-Jihad. Sambutan hangat datang dari salah seorang jamaah Muhammadiyah dari Banjarmasin, yaitu Saifullah, dia adalah jamaah Muhammadiyah pertama di Banjarmasin yang meyakini manhaj Salaf adalah manhaj yang benar. Dukungan dari Saifullah membuka pintu dakwah 
Salaf di Banjarmasin dan pada akhirnya mereka dapat ceramah di masjid-masjid Muhammadiyah seperti masjid al-Ummah.

Berhubung Saifullah adalah seorang pimpinan masjid al-Ummah, maka dia mengundang ustadzustadz Salafi untuk mengisi ceramah di masjid ini. Jamaah Muhammadiyah yang lain merasa resah dengan keberadaan mereka. Pada awalnya mereka menyangka bahwa dakwah yang dibawa oleh ustadzustadz Salafi sama dengan Muhammadiyah tetapi ternyata tidak. Perbedaan tersebut meliputi masalah penetapan satu Syawwal, cara sholat dan yang lainnya. Pada tahun 2008, orang-orang Salafi tidak diberi kesempatan lagi untuk mengisi ceramah agama di masjid Muhammadiyah karena sudah dianggap sebagai kelompok yang berani mengatakan Muhammadiyah melenceng dari Sunnah.

Akibat kejadian ini, maka da'i-da'i Salafi tidak bisa lagi memasuki masjid Muhammadiyah di Banjarmasin dan pada akhirnya mereka menggelar pengajian di rumah-rumah jamaah Salafi. Salah satunya adalah di rumah Saifullah dan beberapa tempat lainnya yang dimiliki oleh Jamaah Salafi seperti Showroom Mobil Suzuki milik H. Hamsan. Satu tahun kemudian (2009-2010), mereka membangun masjid yang diberi nama dengan masjid Imam Syafi'i dan selesai pada tahun 2013. Kejadian serupa juga terjadi di Barabai (2013), oleh sebab itu, di sana juga dibangun masjid Salafi sendiri yang diberi nama masjid al-Umm, begitu juga di Martapura mereka membangun masjid yang diberi nama dengan Syarifah Sholehah (2012).

\section{Sebaran dan Aktifitas Salafi di Kalimantan Selatan}

\section{Kota Banjarmasin}

a. Masjid Imam Syafi'i

Masjid Imam Syafi'i berada di Jalan AMD, kelurahan Pemurus, Banjarmasin, tepat berseberangan dengan SMPN 19 Banjarmasin. Aktivitas Salafi di masjid Imam Syafi'i dapat dibagi ke dalam tiga bagian, yakni ta'lim umum (laki-laki dan perempuan), tempat pendidikan al-Qur'an (TPA), dan kegiatan sosial.

Tausiyah Umum.

Kegiatan ini diadakan dari Senin hingga Jum'at, sesudah sholat subuh hingga selesai. Adapun kitab yang diajarkan adalah kitap tafsir al-Sa'di yang ditulis oleh Abdurrahmân ibn Nâshir al-Sa'di atau bisa juga disebut dengan Tafsîr al-Karîm al-Rahnân bi Tafsîr Kalâm al-Mannân. Kitab tafsir ini diajarkan oleh Ustadz Ahmad Zainuddin. Adapun jadwal pengajian untuk hari Senin ba'da Maghrib adalah kajian Kitab Bulügh al-Marâm. Setiap Rabu ba'da Maghrib adalah kajian Kitab al-Taubîd karya Muhammad ibn Abdul Wahhâb. Setiap Kamis ba'da Maghrib adalah kajian Kitab Riyâdh al-Shâlihîn. Setiap Jum'at ba'da Ashar adalah Fiqih Wanita kajian khusus akhwat. Setiap Senin ba'da Subuh adalah Kajian Fiqih Doa dan Zikir. Setiap Sabtu jam 09.00 hingga selesai adalah Kajian BBA (Belajar Bahasa Arab menggunakan Kitab al-Muyassar fi Tlmi al-Nahwi). Hari Jum'at sesudah sholat Subuh hingga selesai diajarkan kitab Fiqih dan do'a-do'a karya Syekh Abdurrazzaq ibn Abdul Munsin al-Abdad al-Badr. Hari Ahad sesudah sholat subuh hingga selesai diajarkan kitab Sirah Nabawiyah karya Ibnu Hisyam. Semua kajian tersebut dipimpin oleh Ust. Ahmad Zainuddin, Lc. Adapun setiap Sabtu ba'da Ashar diisi bergantian oleh para ustadz tiap pekan. 
Malam Jum'at setelah sholat magrib hingga selesai yang diadakan satu bulan satu kali tepat berada pada awal bulan, dengan menggunakan metode ceramah umum seputar keagamaan yang diisi oleh Ustadz Ahmad Zainuddin dan semua ustadz-ustadz Salafi.

Adapun ustadz-ustadz yang mengisi untuk kegiatan pengajian mingguan adalah ustadz-ustadz Salafi yang ada di Kalimantan Selatan walaupun kadang-kadang dihadirkan ustadz-ustadz yang berada di luar Kalimantan, namun yang paling sering mengisi pengajian tersebut adalah sebagai berikut:

1) Ust. Ahmad Zainuddin, Lc. (pekan pertama)

2) Ust. Febriansyah Riza, S.H.I (pekan kedua)

3) Ust. Aiman Abdullah, Lc. (pekan ketiga)

4) Ust. Khairullah, Lc. (pekan keempat)

5) Ust. Hasby Ridhani, Lc. (pekan kelima)

- Tempat Pendidikan Al-Qur'an (TPA)

Tempat pendidikan al-Qur'an yang diberi nama dengan TPA Imam Syafi'i diresmikan pada 1 April 2014. Tempat pendidikan al-Qur'an ini didirikan untuk mendidik anak-anak yang tidak pandai membaca al-Qur'an. Tempat pendidikan al-Qur'an ini tidak dikhususkan hanya kepada anak-anak Salafi saja, tetapi ditujukan kepada semua masyarakat sekitar baik dari Pemurus hingga Kelayan, Grilya. TPA Imam Syafi'i digratiskan untuk semua kalangan. Ketika mendaftarkan diri maka akan mendapatkan baju seragam, bukubuku dan alat-alat keperluan sekolah lainnya. Adapun gaji pengajar di TPA Imam Syafi'i ini sebesar lima ratus ribu rupiah perbulan, uang ini murni dari infaq dari para jama'ah Imam Syafi'i.

- Kegiatan Sosial

Ada beberapa program yang dilaksanakan dalam acara kegiatan sosial tersebut di antaranya adalah sunatan masal dan bazar murah atau sembako murah.

b. Masjid al-Salam

Masjid al-Salam adalah masjid yang dimiliki oleh Dinas Pendapatan Daerah Provinsi Kalimantan Selatan tepat berada di bagian belakang gedung tersebut. Tidak terlalu banyak aktifitas yang dilakukan di masjid ini, karena jarak antara Masjid al-Salam dengan Masjid Imam Syafi'i tergolong dekat, banyak jamaah Salafi yang lebih memilih Masjid Imam Syaf'i untuk melaksanakan kegiatan. Berikut adalah aktifitas Salafi di Masjid al-Salam Banjarmasin:

- Sholat Lima Waktu

Yang pasti dilakukan oleh kelompok Salafi di Masjid al-Salam ini adalah sholat lima waktu, Zuhur dan Ashar, jamaahnya terdiri dari para pegawai samsat, sedangkan untuk waktu Maghrib, Isya dan Subuh, jamaah yang mengisi adalah jamaah Muhammadiyah dan juga yang utama jamaah Salafi.

- Pengajian

Pengajian kelompok Salafi di Masjid al-Salam dilaksanakan pada hari Jum'at sesudah sholat Magrib dengan metode ceramah tematik yang diisi oleh ustadz-ustadz Salafi di Kalimantan Selatan dengan menggunakan pembagian pekan atau minggu sebagaimana masjid-masjid Salafi lainnya. 
c. Masjid Baitul Hikmah

Masjid Baitul Hikmah berada di lingkungan Kampus Universitas Lambung Mangkurat (Unlam), Jl. Brigjend. H. Hasan Bashri, Kayutangi, Banjarmasin. Tidak banyak kegiatan yang dilakukan oleh kelompok Salafi di Masjid Baitul Hikmah yaitu hanya sebagai berikut:

- Sholat lima waktu.

Karena masjid ini terletak di lingkungan kampus, maka mayoritas yang sholat di sini adalah mahasiswa Unlam dan juga para dosen. Dua pihak inilah yang sholat dan meramaikan masjid ini di waktu Zuhur dan juga Ashar, sedangkan Salafi di waktu ini tidak aktif, atau bisa dikatakan sangat minim satu atau dua orang. Namun di luar waktu ini seperti Maghrib, Isya dan juga Subuh, maka yang mengisi masjid ini adalah kelompok Salafi namun jamaahnya juga tidak terlalu banyak karena kebanyakan memilih sholat di Masjid Hasanuddin Al-Majedi bundaran Kayu Tangi Banjarmasin. Orang-orang Salafi dan juga Muhammadiyah lebih memilih sholat di masjid ini, karena masjid ini bersifat netral, namun tetap menggunakan cara beribadah seperti Muhammadiyah, jadi Salafi tidak keberatan untuk sholat di masjid ini.

- Pengajian

Pengajian di Masjid Baitul Hikmah diadakan pada hari Minggu setelah sholat Maghrib. Dengan sistem pengajian tematis yang menggunakan juga meggunakan jadwal pekan untuk daftar penceramah. Salah satu contoh tema yang diangkat pada pengajian di masjid ini adalah: "Lisanmu Surga dan Neraka bagimu" pengajian diliksanakan pada Hari Selasa, 3 Juli 2012 / 13 Sya’ban 1433 H.

d. Masjid al-Syifa Rumah Sakit Ulin Banjarmasin.

Masjid al-Syifa merupakan masjid yang dimiliki oleh Rumah Sakit Ulin Banjarmasin untuk memberikan fasilitas yang lebih terhadap keluarga orang yang sakit. Sehubungan dengan bangunan masjid ini berada di area Rumah Sakit Ulin dan jauh dari tempat tinggal masyarakat, maka masjid ini hanya digunakan sebagai wadah untuk pengajian atau ta'lim saja oleh Salafi. Adapun jadwal ta'lim di Masjid al-Syifa ini yaitu pada hari Minggu pukul 08.00 sampai jam 10.00 dengan penceramah Ustadz Zuhair dengan materi kitab 'Arbaîn al-Nawâwî.

Selain di masjid-masjid sebagaimana disebutkan di atas, kegiatan dakwah juga marak dilakukan di majlis ta'lim-majlis ta'lim, yaitu:

a. Majlis Ta'lim Setia

Majlis Ta’lim Setia berada di Jalan. Ahmad Yani. Km 7,4. Komplek Permata Bunda Banjarmasin, atau berada di Rumah H. Bambang. Majlis ta'lim ini bersifat umum yang mampu menampung hingga 200 jamaah dengan dilengkapi pendingin ruangan, pengeras suara, perpustakaan kecil yang bersisi buku-buku keislaman. Diantara kitab yang diajarkan adalah karya Syekh Abu Usamah Sâlim ibn 'Id al-Hilali yang berjudul "Mengapa Saya Memilih Manhaj Salaf" oleh Ustadz Ahmad Zainuddin, Lc., kitab Adab al-Murâd karya Imam Bukhari yang disampaikan Ustadz Febriansyah, S.H.I, kitab Zubdat al-Tafsîr (Tafsir Juz. Amma) yang ditulis oleh Dr. Sulaimân al-Asyqar, disampaikan oleh Ustadz Ayman Abdullah Lc., al-Nubdz̧ah fi al'Aqîdah (Syarthu Ushûl al-Îmân) karya Syaikh Muhammad ibn Sholeh al-Utsaimin yang disampaikan oleh Ustadz Khairullah, Lc., dan kitab Fiqh Muammalat yang disampaikan oleh Ustadz Hasbi Ridhani. 
b. Majlis Ta'lim Ar-Rahmat

Majlis Ta'lim Ar-Rahmat berada di Jalan A.Yani Km. 6 tepat berada di depan Stasiun Televisi TVRI Banjarmasin. Majlis ta'lim ini berada di lantai tiga showroom Suzuki Rahmat yang dimiliki oleh H. Hamsan, sebelum kelompok Salafi eksis di Kota Banjarmasin, majlis ta'lim ini adalah wadah bagi kelompok Muhammadiyah untuk mereka melakukan ta'lim, akan tetapi setelah kelompok Salafi eksis dan sehubungan dengan orang yang memiliki majlis ta'lim ini pindah paham ke Salafi maka tergeserlah kelompok Muhammadiyah hingga sekarang majlis ta'lim ini diisi oleh Salafi. Adapun aktifitas Salafi di Majlis Ta'lim Ar-Rahmat adalah sebagai berikut

1) Ta'lim

Adapun jadwal ta'lim di majlis Ta'lim Ar-Rahmat ini adalah hari Minggu pukul 07:30 Wita sampai dengan selesai dengan teknik ceramah tematik.

2) Koperasi dan Jual Beli

Selain aktifitas menuntut ilmu di majlis ta'lim ini juga terjadi jual beli dan koperasi yang dibuka pada lantai dasar atau lantai utama. Setelah para ibu-ibu atau bapak-bapak selesai mengkaji agama maka berduyun-duyunlah untuk berbelanja ke lantai dasar. Adapun bahan jualan yang diperdagangkan oleh jamaah Salafi itu sendiri di antaranya adalah madu, pakain khas Salafi, buku-buku, minyak wangi, peci dan lain-lain yang berhubungan dengan Sunnah Rasul. Di sisi lain terdapat penjaga yang sedang menjaga koperasi Ar-Rahmah yang melayani pembayaran anggota koperasi dan pembayaran utang.

3) Koperasi Ar-Rahmah

Koperasi ini (kantor operasional) berada di Jalan Arjuna IV Nomor 18, Komplek Bumi Pemurus Permai, Kelurahan Pemurus Dalam, Banjarmasin. Alamat kantor secretariat ada di Gedung Suzuki Rahmat Mobilindo Lt. 3 Jl. A.Yani km. 6, Seberang TVRI Kalsel Banjarmasin. Koperasi Syari'ah Ar-Rahmah ini berada dibawah naungan Yayasan AlUmm yang merupakan sebuah yayasan untuk membangun dan mengembangkan gerakan Salafiyah di Kalimantan Selatan. Koperasi ini mempunyai beberapa alternatif cara untuk berinteraksi dengan pihak pengelola. Yang pertama adalah e-mail ksarrahmah@gmail.com/ ksarrahmah@yahoo.com. Yang kedua adalah website http:/ Lksarrahmah.wordpress.com.

Ada beberapa kegiatan Salafi di Koperasi Ar-Rahmah ini. Diantaranya adalah menerima keanggotaan koperasi. Adapun untuk menjadi anggota koperasi Ar-Rahmah maka harus mendaftarkan dirinya terlebih dahulu dengan mengisi formulir dan beberapa persyaratan lainnya seperti; fotocopy KTP, kartu keluarga dengan membayar biaya pendaftran sebesar Rp. 100.000,dan diwajibkan membayar iuran sebesar; Rp. 25.000,-/bulan. Maka bagi orang yang telah aktif menjadi anggota koperasi, nanti pada akhir tahun akan mendapatkan bonus atau bagi hasil dari koperasi berupa produk-produk elektronik yang diberikan kepada anggota. Selain untuk pembentukan keanggotaan koperasi, koperasi Ar-Rahmah juga mengadakan sistem hutang berupa barang elektronik namun tidak untuk menghutangkan uang.

\section{Kota Martapura}

\section{Masjid Syarifah Sholehah}

Masjid Syarifah Sholehah berada di Jalan Muslim Komplek Sa'adah III tepat berada di belakang SMP 4 Sungai Paring Martapura Kalimantan Selatan. Masjid ini didirikan pada tahun 2009 dan 
diresmikan pada tahun 2011. Ada dua kategori aktivitas yang diadakan oleh pengelola masjid Syarifah Sholehah, yaitu tausiyah dan ta'lim Al-Qur'an.

a. Tausiyah Umum

Jamaah yang dapat berhadir dalam tausiyah ini adalah para laki-laki dan ibu-ibu baik dari Banjarbaru, Banjarmasin, Kapuas, Barabai, Amuntai, Alabio dan wilayah lainnya.

b. Ta'lim Al-Qur'an Khusus Ibu-ibu Jadwal kegiatan ini adalah hari Rabu dan Kamis pukul 10:00 hingga selesai.

c. Tahfizh al-Qur'an

Kegiatan ini dilakukan setiap hari kecuali hari Jum'at. Adapun waktu kegiatan ini dimulai setelah sholat Subuh hingga sholat Zuhur dan kegiatan ini boleh diikuti oleh ibu-ibu dan juga laki-laki.

d. Tahsin al-Qur'an

Kegiatan Tahsin al-Qur'an ini ditujukan kepada ibu-ibu dan bapak-bapak. Adapun mengenai waktu tahsin tersebut adalah setiap malam Senin sesudah sholat Maghrib yang diajarkan oleh ustadz-ustadz Salafi yang ahli dalam ilmu al-Qur'an salah satunya adalah Ustadz Aiman.

e. Ta'lim al-Qur'an untuk Anak-anak

Kegiatan orang-orang Salafi lainnya di Masjid Syarifah Soleh adalah ditujukan kepada anakanak yaitu pendidikan TK al-Quran dan Tahfizh al-Qur'an. Kegiatan ini dilakukan setelah sholat Jum'at hingga selesai. Adapun mengenai anak-anak yang menempuh pendidikan di sini adalah anak-anak dari orang-orang Salafi sendiri yang datang dari Banjarbaru atau luar wilayah Banjarbaru.

f. Sekolah Dasar (SD) dan SMP Islam Tahfizh al-Qur'an

Sekolah Dasar Islam Tahfizh al-Quran yang diberi nama dengan "Bakkah", didirikan pada tahun 2011 dan selesai pada tahun 2012. Sekolah ini merupakan sekolah tahfizh pertama yang ada di Kalimantan Selatan yang dimiliki oleh Salafi. Adapun mengenai jumlah santri yang menetap di sekolah dasar ini sebanyak 12 orang yang terdiri dari laki-laki berasal dari Sulawesi, Pontianak, Riau, Samarinda, Sungai Danau.

g. Penyiaran Radio Gemma Madinah

Salah satu kegiatan yang dilakukan oleh Salafi di Masjid Syarifah Sholehah adalah penyiaran radio yang diberi nama dengan "Gemma Madinah". Radio ini menyiarkan ajaran-ajaran murni Islam (Ablu al-Sunnah wa al-Jama’ah).

\section{Kota Barabai}

a. Masjid al-Umm Barabai

Masjid al-Umm berada di Desa Banua Binjai, Komplek Bulau Indah Hulu Sungai Tengah Kalimantan Selatan. Masjid ini diresmikan pada 9 Mei 2012 mempunyai bangunan yang tergolong mewah, dan mempunyai satu menara tinggi dan dilengkapi dengan satu unit mobil operasional (ambulance). Mengenai aktifitas Salafi di masjid ini diantaranya adalah sholat lima waktu berjamaah dan ta'lim. Kitab yang diajarkan untuk saat ini adalah Fiqih Sunnah, Hayat alNufûs, Riyâdh al-Shâlihîn dan kitab tauhid yang diisi oleh Ustadz Hasbi Ridhoni.

b. Musholla An-Nur Barabai

Musholla An-Nur terletak di Kampung Arab tepat berada di samping Bank BRI kota Barabai. Adapaun aktifitas Salafi di musholla ini adalah ta'lim. Jadwal ta'lim di Musholla An-Nur hanya satu kali dalam seminggu yaitu hari Senin setelah sholat Maghrib yang diisi oleh Ustadz Hasbi Ridhani. 


\section{Kota Balangan}

\section{Stasiun Pengisian Bahan Bakar (SPBU)}

Stasiun Pengisian Bahan Bakar Umum (SPBU) ini milik PT. PUTRI SUKSES MANDIRI, yang merupakan salah satu jamaah Salafi di Kabupaten Balangan. Salah satu pekerja di SPBU di sini adalah Ustadz Febriansyah Riza yang bertugas sebagai pengawas dengan menggunakan pakaian SPBU berwarna hitam. Ada beberapa ciri khas dari SPBU ini yang menjadi tanda eksisnya Salafi di Balangan, yaitu sebagai berikut:

a. Para pegawai menggunakan celana tidak isbal, artinya celana berada di atas mata kaki.

b. Para pegawai memanjangkan jenggot.

c. Para pegawai wanita menggunakan pakain sangat tertutup.

Hal lain yang menarik pula di SPBU ini adalah SPBU ini mewajibkan kepada semua pegawainya untuk sholat berjamaah tiap waktu selama SPBU buka (jam kerja). Hal ini dapat dilihat saat waktu sholat tiba, SPBU ini ditutup dan diletakkan di bagian depan tulisan yang berbunyi "Ma'af Sedang Sholat \pm 20 Menit". Jika waktu sholat tiba bukan hanya para pegawai yang sholat berjamaah, tetapi juga para pelanggan yang mengetahui aturan tersebut juga ikut sholat. Selain tempat pengisian bahan bakar di SPBU ini, juga terdapat musholla. Musholla ini juga dijadikan sebagai wadah pengajian Salafi di Balangan.

Sehubungan dengan Salafi di Balangan tidak mempunyai masjid, maka pengelola yang diwakilkan kepada Ustadz Febri membuat jadwal ta'lim di Musholla SPBU ini. Adapun jadwal ta'lim di musholla ini adalah setiap waktu sholat dengan tiga tema, yaitu bidang aqidah atau tauhid yang merujuk kepada karya Muhammad ibn Abdul Wahhab, kemudian bidang adab sehari-hari dan yang terakhir adalah bidang Fiqih.

Masyarakat sekitar dan juga tokoh ulama setempat memberikan apresiasi atas peraturan dan aktifitas sangat religius yang telah dilaksanakan di SPBU tersebut. Jamaah Salafi Balangan juga akan mempunyai masjid Salafi sendiri tepatnya didirikan di Batu Mandi Kabupaten Balangan Kalimantan Selatan yang masih dalam tahap perencanaan.

\section{Media Dakwah Salafi di Kalimantan Selatan}

\section{Media Cetak}

a. Buku

Ada beberapa percetakan di luar Kalimantan yang mendukung aktivitas Salafi di Kalimantan Selatan di antaranya adalah: Al-Huda, Ash-Shaf Media, At-Tibyan, Cahaya Tauhid Press, Daar An-Naba, Daarul Iman, Dar-Hujjah, Darul Atsar, Darul Falah, Darul Hadits, Darul Haq, Darul Ilmi, Darul Qalam, Darul Qolam, Darul Salaf, Darul Sunnah, Maktabah Salafi Press, Media Hidayah, Media Tarbiyah, Mubarak, Nikah Media Samara, Pustaka Abdullah, Pustaka Adz-Dzahabi, Pustaka AL-Ghuraba, Pustaka Al-Haura, Pustaka Al-Inabah, Pustaka Al-Qawwan, Pustaka Al-Sofwa, Pustaka Al-Haura, Pustaka An-Najiah, Pustaka Arafah, Pustaka Ar-Rayyang, Pustaka As-Sunnah, Pustaka At-Taqwa, Pustaka At-Tauhid, Pustaka At-Tazkia, Pustaka At-Tibyan, Pustaka Azzam, Pustaka Elba, Pustaka Ibnu Katsir, Pustaka Imam Abu Hanifah, Pustaka Imam Bukhari, Pustaka Imam Muslim, Pustaka Imam Syafi'I, Pustaka Mustaqim, Pustaka Sahifa, Pustaka Salafiyah, Pustaka Sumayyahm Pustaka Sunnah, Pustaka Tauhid, Pustaka Ulil Albab, Rumah Dzikir, Pustaka Ibnu 'Umar, Pustaka Aqwam. 
Diantara buku-buku yang telah diterbitkan seperti; Abdul Aziz Asy-Syinawi, Biografi Imam Abu Hanifah dan Biografi Imam Ahmad (Aqwam), Yazid Abdul Qadir Jawaz, Mulia Dengan Manhaj Salaf (Pustaka At-Taqwa), Syaikh Ahmad Farid, 60 Biografi Ulama Salaf (Pustaka Al-Kausar), Abdul Aziz Nastir Al-Julail, Kita dan Akhlak Salaf (Aqwam), Muhammad Sulaiman 'Abduh al-Asyqar, Tafsir Juz 'Amma (Pustaka Ibnu Kastir), Syaikh Abu Usamah, Mengapa Memilih Manhaj Salaf (Pustaka Imam Bukhari).

Salah satu cara yang dilakukan oleh para pendakwah Salafi yang ada di Kalimantan Selatan atau para jamaah Salafi untuk memudahkan aktivitas mereka dalam berdakwah adalah dengan membagi-bagikan buku-buku yang bersangkutan dengan apa yang mereka pelajari secara gratis. Buku-buku itu merupakan hasil dari kerja sama dengan penerbit dan juga sumbangan dari para donator-donatur jamaah Salafi sendiri. Contoh di Masjid Imam Syafi'i, Majlis Ta'lim Setia yang ada di Banjarmasin, kedua tempat ini sering membagi-bagikan buku secara gratis kepada para jama'ah yang ingin duduk mendengarkan ceramah agama yang mereka laksanakan. Contoh buku-buku yang mereka berikan adalah; Syaikh Abu Usamah Salim ibn 'Id al-Hilali, Mengapa Memilih Manhaj Salaf, Muhammad Sulaiman 'Abduh al-Asyqar, Tafsir Juz 'Amma, Tim Penulis MUI Pusat, Mengenal \& Mewaspadai Penyimpangan Syi'ah di Buletin Jum'at

Aktivitas Salafi lainnya yang ada di Kalimantan Selatan adalah aktifnya mereka untuk menyebarkan paham pada media cetak yaitu buletin Jum'at yang ditulis dan diterbitkan sekali dalam seminggu. Buletin Jum'at ini juga yang menjadi tanda berkembangnya Salafi di Kalimantan Selatan. Adapun buletin Jum'at tersebut diberi nama dengan "Imam Syafi'i". Adapun tema pembahasan dalam buletin ini tentu masalah ilmu-ilmu keislaman yang sesuai dengan sl-Qur'an dan Sunnah seperti; "Adakah Sifat Munafik dalam Sholat Saya". Buletin ini dari awal terbitnya hingga sekarang masih ditulis tetap oleh Ahmad Zainuddin.

b. Kalender

Ada beberapa perbedaan yang bisa digambarkan antara kalender buatan Salafi dengan non-Salafi, di antaranya adalah: Pertama, jika Muhammadiyah membuat kalender dengan hiasanhiasan perkembangan organisasi mereka baik dalam pendidikan hingga politik. Tetapi tidak bagi Kelompok Salafi, mereka membuat kalender dengan hiasan pesan-pesan keagamaan dengan menghilangkan gambar-gambar yang menurut mereka itu tidak boleh.

Kedua, kelompok Salafi mengedepankan bulan Hijriah dibandingkan dengan bulan Masehi karena sekali lagi bulan Hijriah adalah bulan orang-orang Islam.

Ketiga, jika organisasi keagamaan pada umumnya seperti Muhammadiyah dengan gambar yang mencolok, tetapi hal tersebut berbeda dengan kelompok Salafi, mereka tidak menggunakan gambar-gambar yang mencolok, tetapi mereka menggunakan nasehat-nasehat keagamaan seperti fatwa ulama Salaf hingga hadis-hadis Rasul.

Keempat, pada kalender buatan Salafi di Kalimantan Selatan adalah adanya tanda-tanda yang terletak paling bawah dalam hitungan satu bulan yang berwarna-warna. Warna tersebut menandakan puasa-puasa yang disunnahkan oleh Rasulullah Saw. Adapun tanda-tanda warna tersebut seperti berikut: merah hati menandakan hari puasa Tasu'a, warna ungu menandakan puasa hari 'Asyura dan warna hijau menandakan puasa Baidh.

c. Spanduk dan brosur (iklan)

Keaktifan Salafi di Kalimantan Selatan khususnya di Kota Banjarmasin turut diapresiasi karena pemanfaatan media yang begitu aktif walaupun tergolong baru. Fenomena ini dapat 
dibuktikan dengan banyaknya spanduk-spanduk dan juga brosur yang diletakkan di pinggirpinggir jalan dan dibagi-bagikan kepada jamaah masjid. Hal ini dilakukan saat ada undangan pengajian-pengajian baik dari Ulama Timur Tengah ataupun Indonesia sendiri.

Salah satu spanduk yang sangat banyak diletakkan di pingir-pinggir jalan adalah spanduk seminar Syi'ah dan juga tabligh akbar, dan begitu juga dalam kegiatan pengajian besar selalu diumumkan dengan menggunakan spanduk dan brosur. Cara ini memberikan hasil yang sangat positif bagi perkembangan Salafi di Kalimantan Selatan.

d. Undangan

Setiap kali ada pengajian yang diisi oleh ustadz-ustadz Salafi dari luar daerah maka cara yang dilakukan untuk meramaikan pengajian tersebut yaitu dengan mengirimkan undanganundangan resmi ke masjid-masjid tertuju kepada semua jamaah dan Ketua Ta'mir, perihal undangan untuk menghadiri pengajian. Salah satu contoh dalam kasus ini adalah Masjid alUmmah yang beramatkan di Jalan Arjuna VI Rt. 22. No. 2 Komplek Bumi Pemurus Permai Banjarmasin yang menjadi salah satu tempat undangan tersebut ditujukan.

\section{Media Elektronik}

a. Televisi

Stasiun televisi kepemilikan Salafi adalah TV Rodja. Sejarah TV Rodja pada awalnya hanya sebuah siaran radio yang bernama dengan Radio Rodja yang dirintis pada bulan Mei 2005 yang bertempat pada saluran FM. Kemudian dengan berkembangnya dan dukungan dari masyarakat maka kualitas Radio Rodja meningkat menjadi frekuensi $756 \mathrm{KHz}$ (AM) di tahun 2007. Perkembangan Radio Rodja semakin cepat hingga bisa dinikmati hampir di semua Nusantara baik dari radio analog (756 AM) maupun radio streaming.

Setelah berkembangnya radio Rodja maka diciptakanlah Rodja TV pada tahun 2009 dengan cara streaming Internet (TV streaming). Dengan banyaknya dukungan dan bantuan dari masyarakat Salafi sendiri maka Rodja tidak lagi hanya bisa dinikmati melalui internet tetapi sudah bisa dinikmati melalui satelit dengan menggunakan perangkat parabola tepat pada tahun 2011 dengan alamat kantor sekretariat Studio Radio Rodja dan Rodja TV Jl. Pahlawan (belakang Polsek Cileungsi) Kp. Tengah RT.03/ RW.03 Kecamatan Cileungsi, Bogor.

Bagi orang-orang Salafi menonton acara televisi pada zaman sekarang sangat tidak pantas, bahkan menjadi sebuah dosa. Untuk itu dengan adanya stasiun televisi Rodja TV menjadi alternatif pilihan utama untuk menghindari dosa-dosa saat melihat acara di layar TV yang mayoritas para artis membuka aurat. Untuk itu, ada himbauan dari semua ustadz-ustadz Salafi yang ada di Kalimantan Selatan agar jangan pernah sekali-sekali menonton acara televisi kecuali di stasiun Rodja TV yang hanya menayangkan ceramah agama dan tilawati al-Qur'an.

Bahkan bukan hanya sampai di situ, ustadz-ustadz Salafi sekarang juga sudah masuk televisitelevisi Kalimantan Selatan seperti BanjarTV setiap kamis malam ditayangkan ceramah agama dari ustadz-ustadz Salafi, bukan hanya BanjarTV bahkan TVRI juga mengundang ustadz Salafi untuk ceramah di salah satu acara mereka, Kamis malam sekitar pukul 7:30, contoh: Kamis tanggal 11 Desember 2014 pihak TVRI mengundang Ustadz Khairullah ceramah dengan tema masalah ketauhidan. 
b. Radio

Pusat peniyiaran radio yang dimiliki oleh Salafi ini berada di bagian samping Masjid Syarifah Sholehah di Jalan Muslim Komplek Sa'adah III tepat berada di belakang SMP 4 Sungai Paring Martapura.Bertepatan pada tanggal 1 November 2011 diadakan rapat untuk perencanaan pembangunan sebuah radio yang menyiarkan ajaran Salafu al-Shâlih. Berdasarkan hasil rapat tersebut maka terbentuklah perlindungan hukum yang akan menaungi radio tersebut yaitu PT. Gemma Madinah dengan komisaris utama adalah Saufi Muhsin Thalib dan Nabi Masjid Thalib. Kemudian resmilah radio ini diberi nama dengan 'Gema Madinah" yang didirikan pada tahun 2012 dengan frekuensi 93,7 FM.

Namun pada masa pembangunan frekuensi yang digunakan hanya 300 watt hal ini menandakan bahwa tidak semua masyarakat Kalimantan dapat mendengarkan radio tersebut, namun tepat pada tanggal 29 November 2013 diadakan rapat kembali dan dibuatkan sebuah proposal untuk memperbaharui alat radio yang dulunya 300 watt menjadi 3500 watt dengan merk ELENOS ETG3500-Italy dengan harga Rp. 162.206.000,-. Mesin baru inilah yang menjadi alat penyiaran radio Gemma Madinah di Kalimantan Selatan.

Selain kegiatan tetap tersebut, radio Gemma Madinah juga digunakan sebagai penyiaran kajian-kajian live dari setiap masjid Salafi yang ada di Kalimantan Selatan, contoh Masjid Syarifah Sholehah. Setiap ada kajian keislaman di masjid ini, maka kajian tersebut langsung ditayangkan pada Frekuensi 93,7 FM hingga dapat didengar hampir di seluruh Kalimantan Selatan. Selain radio yang bersifat frekuensi, ada juga radio yang disebarkan melewati website pribadi milik Salafi dengan situs: www.gemaMadinah.com. Selain itu ada juga dari Facebook dengan nama; "Radio Gemma Madinah".

Fenomena perkembangan Radio Gemma Madinah di Kalimantan Selatan memang cukup patut untuk diapresiasi, dengan keahlian tim-tim dari tangan kelompok mereka, maka Gemma Madinah bisa didengarkan hingga ke pelosok desa. Bukan hal yang tabu lagi ketika berjalan ke suatu desa terdengar ceramah agama di masjid-masjid yang disiarkan langsung melalui sinyal radio dari frekuensi Gemma Madinah, karena mereka mempunyai sinyal yang cukup jernih selain itu tema-tema yang diusung dalam program mereka sangat religius, sesuai dengan masyarakat Kalimantan Selatan. Fenomena ini sudah dibuktikan oleh penulis sendiri pada salah satu rumah warga di Desa Loktangga, mereka selalu mendengarkan radio dengan frekuensi Gemma Madinah, mendengarkan ceramah agama dan juga Qira'at al-Qur'an.

Selain itu, cara yang mereka gunakan juga sangat menarik, mereka promokan frekuensi mereka di setiap kali ada spanduk dalam acara kegiatan mereka yang sering diletakkan di pinggirpinggir jalan. Selain itu, mereka juga mempromokan frekuensi radio mereka secara tunggal dengan satu sapanduk yang diletakan di pinggiran jalan raya tepat di Kota Martapura dengan peletakkan yang sangat strategis.

\section{c. VCD/DVD}

Salah satu cara yang juga dilakukan oleh kelompok Salafi yang ada di Kalimantan Selatan adalah merekam video-video ceramah agama dari ustadz-ustadz Salafi yang ada di Kalimantan Selatan ataupun yang menjadi tamu di tempat-tempat eksis Salafi. Kemudian ceramah-ceramah tersebut direkam dan diperjualbelikan. Gambaran yang menarik dalam kasus ini adalah semua keuntungan dari penjualan kaset tersebut disumbangkan untuk Masjid Imam Syafi'i. Di sisi lain ada perbedaan antara harga jual kaset tersebut. Untuk kaset Ustadz Ahmad Zainuddin dijual 
dengan harga Rp. 25.000,-/kaset, namun jika hanya kaset-kaset yang diisi oleh selain Ustadz Ahmad Zainuddin maka hanya dijual dengan harga Rp. 15.000,-/kaset.

Selain dijual, kaset-kaset tersebut juga banyak yang dibagi-bagikan kepada masyarakat atau jamaah secara gratis, seperti yang telah peneliti dapatkan saat peneliti sedang ikut pengajian di Masjid Sayarifah Sholehah Martapura. Dalam hal ini, kaset yang dibagikan merupakan gambaran kejahatan dan kesesatan kelompok Syi'ah.

\section{Internet}

a. Faceboook

Kelompok Salafi di Kalimantan Selatan juga mengggunakan facebook sebagai media jejaring sosial yang gunanya untuk memberikan nasehat-nasehat dan juga informasi tentang jadwal siaran atau jadwal kegiatan-kegiatan Salafi yang ada di Kalimantan Selatan khususnya yang bisa diliput oleh radio mereka sendiri (Gemma Madinah).

Alamat Facebook yang mereka gunakan berbentuk sebuah grup yang diberi nama dengan: "Radio Gemma Madinah FM Martapura" dengan jumlah anggota sebanyak enam ratus empat puluh enam (646) orang. Adapun pengurus utama grup ini adalah seseorang yang bernama Saufi Thalib, dia yang selalu memberikan informasi mengenai aktivitas Salafi dalam hal kegiatan dakwah.

b. BlackBerry Messenger

Penggunaan aplikasi ini bagi kelompok Salafi di Kalimantan Selatan untuk menginformasikan jadwal-jadwal kajian Islam Manhaj Salafiyah yang ada di Kalimantan Selatan. Selain untuk menginformasikan jadwal-jadwal pengajian, BBM juga digunakan oleh mereka sebagai penyampai nasehat-nasehat singkat berupa bahaya Syiah, bahaya kesyirikan dan yang lainnya. Adapun pin BlackBerry Messenger yang dimiliki oleh mereka adalah: 2ACB8198 dengan email: dmis.bjm@gmail.com.

c. Pesan Instan

Selain via BBM, kelompok Salafi juga menggunakan via pesan instan untuk menginformasikan kegiatan-kegiatan yang akan mereka lakukan seperti informasi jadwal pengajian dan yang lainnya. Cara ini bertujuan untuk memudahkan para jamaah untuk mengetahui informasi kajian tersebut hinggga tidak ketinggalan saat ada kegiatan. Mereka menggunakan pesan, email dan via SMS. Untuk alamat email yang mereka gunakan adalah imamsyafii.bjm@gmail.com.

Salah satu nomor Handpone yang menjadi sumber info tersebut adalah: +628538884844 . Untuk mengikuti dan mendapatkan info kajian dari mereka maka cara yang harus dilakukan pertama kali adalah mendaftarkan nomor handpone dengan cara sebagai berikut: Daftar (sapasi) Info Kajian (spasi) Nama, kirim ke: 083241187227 atau 08538884844.

d. Website

Khusus Salafi di Kalimantan Selatan yang dibawa oleh Ustadz Aiman, mereka mempunyai tiga website sebagai jalan dakwah. Pertama, www.dakwahsunnah.com yang diasuh oleh Ustadz Ahmad Zainuddin. Web ini berisikan materi-materi keagamaan baik video, buku-buku hingga tulisan-tulisan ringan yang berbau keagamaan Ablu al-Sunnah wa al-Jamaah. Jika kita cermati mengenai video-video yang dipasang di web ini sangatlah bagus, rapi dan juga menarik, sistem 
perancangan, peletakkan dan editor kamera tidaklah bisa dilakukan oleh orang yang tidak ahlinya.

Kedua, www.alummbjm.wordpresscom, web ini berisikan informasi mengenai kegaiankegiatan Salafi di Kalimantan Selatan, baik undangan pengajian, informasi pembangunan dan lain-lain. Web ini diasuh oleh Yayasan Al-Umm Banjarmasin dengan alamat sekretariat Jalan Amd III (seberang SMPN 19) Kelurahan Pemurus Dalam Masjid Imam Syafi'i Banjarmasin. Semua informasi kegiatan yang dilakukan oleh Salafi di Kalimantan Selatan terekam di sini. Karena web ini adalah tempat informasi bagi mereka.

Ketiga, www.barabai.al-umm.or.id, web ini dikhususkan untuk kegiatan-kegiatan kelompok Salafi yang ada di Masjid Al-Umm Barabai. Web ini juga berisi mengenai informasi-informasi jadwal pengajian dan kegiatan-kegiatan yang lainnya khusus di Masjid Al-Umm. Adanya perbedaan web antara Barabai dengan Banjarmasin dan juga Martapura karena Barabai terletak lebih jauh dan menyendiri perkembangannya.

Adapun untuk website Salafi yang dibawa oleh Ustadz Aslam di Kalimantan Selatan seperti www.kajianbanjar.info.com. Selain web ini, ada juga web yang menjadi sumber rujukan mereka. Ada dua website yang menjadi kajian keagamaan yang biasa mereka gunakan yaitu: www.salafi.or.id dan www.salafibpp.com. Kedua web ini mengandung beberapa komponen, diantaranya adalah tulisan-tulisan manhaj Salafi sendiri dan juga beberapa buku-buku yang bisa diunduh. Selain itu dua web ini juga berfungsi untuk menginformasikan kegiatan-kegiatan Salafi secara umum, sekitar Jawa. Adapun untuk www.salafibpp.com ini diasuh oleh Ustadz Asykari yang sangat aktif di Balikpapan, dia juga mempunyai pondok pesantren dan jamaah yang sangat banyak.

\section{Penutup}

Sejarah awal masuknya Salafi sebagai ideologi dakwah di Kalimantan Selatan berawal pada tahun 2001 yang dibawa oleh dua orang Ustadz, Aiman dan Mardatillah. Dua orang ustadz inilah yang mendakwahkan Salafi di daerah Amuntai Kalimantan Selatan yang dimulai dari masjid-masjid Muhammadiyah. Dalam masa perkembangan ini, mereka sudah mempunyai beberapa wadah sebagai pusat kajian dan aktivitas mereka seperti masjid, majlis ta'lim, radio hingga unit usaha. Contoh masjid yang mereka miliki adalah Masjid Imam Syafi'i di Banjarmasin, Masjid Syarifah Sholehah di Martapuura, Masjid al-Umm di Barabai. Salah satu cara yang mereka lakukan untuk berdakwah adalah penggunaan ruang publik. Semua media telah digunakan oleh Salafi di Kalimantan Selatan untuk menyampaikan paham yang mereka miliki baik melalui media cetak, media elektronik, bahkan media internet dalam dakwah mereka. Tidak mengherankan jika 20-30 tahun ke depan kalangan Salafi akan merasakan hasil dari pengaruh ruang publik yang selama ini mereka jalankan.

\section{DAFTAR PUSTAKA}

al-Hilali, Syaikh Abu Usamah ibn 'Id. Mengapa Memilih Manhaj Salaf: Studi Kritis Solusi Problematika Umat. Indonesia: Pustaka Imam Bukhari. 2007.

Idahram, Syaikh. Sejarah Berdarah Sekte Salafi Wahabi. Yogyakarta: PT LKiS Printing Cemerlang. 2011.

- Ulama Sejagat Menggugat Salafi Wahabi. Yogyakarta: PT LKiS Printing Cemerlang. 2012.

Jawas, Yazid ibn Abdul Qadir. Mulia Dengan Manhaj Salaf. Jawa Barat: Pustaka At-Taqwa. 2013. 
Jum'ah, Ali. Menjawab Dakwah Kaum Salafi. Jakarta: Khatulistiwa Press. 2013.

Mujahid, Abu. Sejarah Salafi di Indonesia. Bandung: Tim Toobagus Publishing. 2012.

Mujiburrahman. Mengindonesiakan Islam, Representasi dan Ideologi. Yogyakarta: Pustaka Pelajar. 2008.

Najid, Agus Moh. dan Yudian Wahyudi. Gerakan Wababi di Indonesia: Dialog dan Kritik. Yogyakarta: Bina Harfa. 2009.

Najid, Moh. dkk. Gerakan Wahabi di Indonesia (Dialog dan Kritik). Yogyakarta: Pesantren Nawesea Press. 2009.

Radjab, Muhammad. Perang Padri di Sumatra Barat (1803-1838). Jakarta: Perpustakaan Kementrian P.P dan K. 1954.

Za'rur, Labu. Seputar Gerakan Islam. Bogor: Al-Azhar Press. 2014.

http://abiubaidah.com/biografi-singkat-syaikh-abdurrazzaq-ibn-abdul-mubsin-al-abbad-al-badr.html/.

http://ibh3.wordpress.com/sirah-nabawiyah/proses-penulisan-sirah-nabawaiyah-dan-biografi-ibu-bisyam/

http//id.wikipedia.org/wiki/ibnu_Hajar_al-asqalani.

http://www.radiorodja.com/profil-radio-rodja-dan-rodjatv/\#ixzz3AXZqS8zv.

https://www.facebook.com/Radio.Gema.Madinah.93.7FM?fref=grp_mmbr_list. 